Case Report

\title{
Rhabdomyolysis Induced by Nonstrenuous Exercise in a Patient with Graves' Disease
}

\author{
Sarawut Summachiwakij $^{1}$ and Issac Sachmechi ${ }^{2}$ \\ ${ }^{1}$ Department of Medicine, Icahn School of Medicine at Mount Sinai, Queens Hospital Center, Jamaica, New York, NY 11432, USA \\ ${ }^{2}$ Division of Endocrinology, Icahn School of Medicine at Mount Sinai, Queens Hospital Center, Jamaica, New York, NY 11432, USA
}

Correspondence should be addressed to Sarawut Summachiwakij; artmdsi@gmail.com

Received 13 December 2013; Accepted 6 January 2014; Published 11 February 2014

Academic Editors: T. Kita and Y. Moriwaki

Copyright (C) 2014 S. Summachiwakij and I. Sachmechi. This is an open access article distributed under the Creative Commons Attribution License, which permits unrestricted use, distribution, and reproduction in any medium, provided the original work is properly cited.

\begin{abstract}
Hyperthyroidism can result in several musculoskeletal conditions such as thyrotoxic periodic paralysis, thyrotoxic myopathy, and thyroid ophthalmopathy. Rhabdomyolysis has been rarely reported to be associated with hyperthyroidism. We describe a 33-yearold man who presented with bilateral thigh pain and dark brown urine after regular squatting. He had a past medical history of hyperthyroidism but stopped taking it 2 months prior to admission. He was found to have rhabdomyolysis, myoglobinuria, and thyrotoxicosis. Presence of thyroid-stimulating immunoglobulins (TSI) and high radioiodine uptake confirmed a diagnosis of Graves' disease. He received aggressive fluid resuscitation and sodium bicarbonate intravenously along with monitoring fluid and electrolyte. Methimazole was also resumed. The patient responded to treatment and rhabdomyolysis gradually resolved. Therefore, nonstrenuous exercise can potentially induce rhabdomyolysis in patients with hyperthyroidism. Although hyperthyroidism is not widely recognized as a cause of rhabdomyolysis, it should be considered in the differential diagnosis of rhabdomyolysis.
\end{abstract}

\section{Introduction}

Rhabdomyolysis is characterized by muscle necrosis resulting in the release of muscle cell content into the circulation. This condition has been occasionally associated with strenuous exercise, hyperthermia, certain infections, and metabolic abnormalities such as diabetic coma, severe electrolyte disturbances, and hypothyroidism [1]. In the English literature, hyperthyroidism has been rarely reported to be associated with rhabdomyolysis [1-6]. We have described the case with hyperthyroidism who developed rhabdomyolysis after nonstrenuous exercise.

\section{Case Presentation}

A 33-year-old male presented with bilateral thigh pain after regular squatting. The patient often squatted for exercise and never developed rhabdomyolysis. On the following day, the patient developed severe bilateral pain and stiffness in both thighs. He took Tylenol for pain and denied using any steroid or illicit drugs. He noticed dark brown-colored urine which urged him to come to the hospital. There was no history of fever, cough, sore throat, headache, blurred vision, palpitations, diarrhea, or abdominal pain. The patient also had a past medical history of hyperthyroidism and was taking methimazole which he stopped 2 months prior to admission. On physical examination, the patient was alert and oriented in no acute distress. His blood pressure was $137 / 77 \mathrm{mmHg}$ and pulse was 100 beats per minute, and he was afebrile. His eyes showed no lid lag or exophthalmos. An examination of neck revealed mild thyroid enlargement on swallowing but not tender. No thyroid bruit was heard. Heart and chest examinations were normal. Examination of thighs showed mild swelling and tenderness. Neurological examination showed no hand tremor, normal muscle power, and deep tendon reflex $2+$ all. The remainder of the physical examination was unremarkable. A chest X-ray and an ECG were normal.

The laboratory findings revealed the following values: blood urea nitrogen $10 \mathrm{mg} / \mathrm{dL}(8-22 \mathrm{mg} / \mathrm{dL})$, creatinine $0.8 \mathrm{mg} / \mathrm{dL} \quad(0.4-1.6 \mathrm{mg} / \mathrm{dL})$, sodium $140 \mathrm{mg} / \mathrm{dL} \quad(136-$ $146 \mathrm{mg} / \mathrm{dL})$, potassium $4.4 \mathrm{mg} / \mathrm{dL}(3.5-5.3 \mathrm{mg} / \mathrm{dL})$, carbon 
TABLE 1: Cases of rhabdomyolysis associated with hyperthyroidism published in the medical literature.

\begin{tabular}{|c|c|c|c|c|c|c|c|}
\hline $\begin{array}{l}\text { Case } \\
\text { number }\end{array}$ & Age/sex & $\begin{array}{c}\text { Past medical } \\
\text { history }\end{array}$ & $\begin{array}{l}\text { Presenting } \\
\text { symptoms }\end{array}$ & $\begin{array}{l}\text { Hyperthyroid } \\
\text { state }\end{array}$ & $\begin{array}{c}\text { Possible } \\
\text { triggering } \\
\text { factors of } \\
\text { rhabdomyolysis }\end{array}$ & Complication/outcome & Reference \\
\hline 1 & $26 / \mathrm{F}$ & NA & $\begin{array}{l}\text { Altered mental } \\
\text { status }\end{array}$ & Thyroid storm & Infection & Acute renal failure/resolved & {$[2]$} \\
\hline 2 & $50 / \mathrm{M}$ & Graves' disease & $\begin{array}{l}\text { Altered mental } \\
\text { status }\end{array}$ & Thyroid storm & NA & $\begin{array}{c}\text { Acute renal failure, heart } \\
\text { failure, liver failure, } \\
\text { DIC/expired }\end{array}$ & {$[3]$} \\
\hline 3 & $20 / \mathrm{M}$ & NA & $\begin{array}{l}\text { Weakness and } \\
\text { muscle cramp }\end{array}$ & Thyrotoxicosis & NA & Resolved & {$[4]$} \\
\hline 4 & $53 / \mathrm{F}$ & NA & $\begin{array}{l}\text { Altered mental } \\
\text { status }\end{array}$ & Thyroid storm & Infection & Acute renal failure/resolved & {$[5]$} \\
\hline 5 & $26 / \mathrm{F}$ & Hypertension & $\begin{array}{l}\text { Blurred vision, } \\
\text { headache }\end{array}$ & Thyrotoxicosis & NA & Resolved & {$[1]$} \\
\hline 6 & $23 / \mathrm{M}$ & NA & Flank pain & Thyrotoxicosis & Exercise & Resolved & {$[6]$} \\
\hline 7 & $33 / \mathrm{M}$ & $\begin{array}{l}\text { Hyperthy } \\
\text { roidism }\end{array}$ & Thigh pain & Thyrotoxicosis & Exercise & Resolved & Present case \\
\hline
\end{tabular}

dioxide $29 \mathrm{mg} / \mathrm{dL}(23-32 \mathrm{mg} / \mathrm{dL})$, chloride $103 \mathrm{mg} / \mathrm{dL}$ (98$110 \mathrm{mg} / \mathrm{dL})$, phosphate $4.6(2.4-4.1 \mathrm{mg} / \mathrm{dL})$, magnesium 1.97 (1.7-2.2 mg/dL), glucose $83 \mathrm{mg} / \mathrm{dL} \quad(74-115 \mathrm{mg} / \mathrm{dL})$, a hemoglobin $16.2 \mathrm{~g} / \mathrm{dL}(13.5-17.5 \mathrm{~g} / \mathrm{dL})$, a white blood cell count $9.3 \mathrm{~K} / \mathrm{mcL}(4.5-11 \mathrm{~K} / \mathrm{mcL})$ with a differential of 72.9 percent neutrophil, 17.7 percent lymphocyte, and 8.2 percent monocyte, platelet $217 \mathrm{~K} / \mathrm{mcL}$ (130-400 K/mcL), CK $98407 \mathrm{IU} / \mathrm{L}$ (26-189 IU/L), thyroid stimulating hormone $0.01 \mathrm{mIU} / \mathrm{mL} \quad(0.34-5.6 \mathrm{mIU} / \mathrm{mL})$, free $\mathrm{T} 4 \quad 1.98 \mathrm{ng} / \mathrm{dL}$ (0.58-1.64 ng/dL), T3 $176.5 \mathrm{ng} / \mathrm{dL}$ (87-178 ng/dL), alkaline phosphatase $66 \mathrm{U} / \mathrm{L}(30-115 \mathrm{U} / \mathrm{L})$, AST $993 \mathrm{U} / \mathrm{L}(2-40 \mathrm{U} / \mathrm{L})$, ALT $228 \mathrm{U} / \mathrm{L}$ (2-50 U/L), LDH $2330 \mathrm{U} / \mathrm{L}$ (90-225 U/L), albumin $2.8 \mathrm{~g} / \mathrm{dL}(3.5-5 \mathrm{~g} / \mathrm{dL})$, total bilirubin $1.63 \mathrm{mg} / \mathrm{dL}$ (normal < $1.5 \mathrm{mg} / \mathrm{dL}$ ), and direct bilirubin $0.39 \mathrm{mg} / \mathrm{dL}$ (normal $<0.3 \mathrm{mg} / \mathrm{dL}$ ). Urinalysis showed a specific gravity of 1.021, blood large, ketone trace, protein $300 \mathrm{mg} / \mathrm{gL}$, red blood cell 0-4, white blood cell 0-4, urine myoglobin $36 \mathrm{mcg} / \mathrm{L}$ (normal <28), and serum myoglobin $2250 \mathrm{mcg} / \mathrm{L}$ (normal 0-60). Urine toxicology was negative. TSH receptor antibody $48 \%$ (normal < 10\%), antithyroglobulin antibody, and anti-thyroid peroxidase antibody were negative.

The patient was diagnosed with rhabdomyolysis and was treated with aggressive intravenous fluid and sodium bicarbonate drip. Urine output and electrolyte were closely monitored. He was started on methimazole for hyperthyroidism. His symptom significantly improved and serum creatinine kinase level also gradually decreased without electrolyte imbalance or acute kidney injury. The patient was discharged home with stable condition and had a radioactive iodine uptake done which showed high radioactive iodine uptake with homogenous activity consistent with Graves' disease.

\section{Discussion}

Musculoskeletal manifestations of hyperthyroidism include thyrotoxic periodic paralysis, thyrotoxic myopathy, and less commonly thyroid ophthalmopathy [5]. Rhabdomyolysis known to be more frequently occurred in hypothyroidism has been rarely reported to be associated with hyperthyroidism.

Theoretically, hyperthyroidism can cause rhabdomyolysis by increasing cellular metabolism and also decreasing muscle energy stores, both of which result in cellular damage [3]. Disturbance in the level of skeletal muscle carnitine may play a role in the pathogenesis. Carnitine which is substance necessary for the production of energy was significantly reduced in skeletal muscle of hyperthyroid patients. The mechanism by which carnitine becomes depleted might be due to an increased esterification and urinary excretion of carnitine [7].

The summaries of cases of rhabdomyolysis associated with hyperthyroidism are detailed in Table 1 . Three cases of rhabdomyolysis occurred in the setting of thyroid storm $[2,3,5]$. One of these cases developed heart failure and liver failure and died of disseminated intravascular coagulation and renal failure [3]. The other cases of rhabdomyolysis did not meet the criteria for thyroid storm $[1,4,6]$ and one case was triggered by a regular exercise session [6]. Therefore, hyperthyroidism should be considered in the differential diagnosis of rhabdomyolysis. Furthermore, in patients who developed rhabdomyolysis after nonstrenuous exercise hyperthyroidism should be ruled out.

\section{Disclosure}

All the authors of this paper agree on the submission, and have nothing to disclose.

\section{Conflict of Interests}

There is no conflict of interests regarding the publication of this paper. 


\section{References}

[1] D. M. Lichtstein and R. B. Arteaga, "Rhabdomyolysis associated with hyperthyroidism," American Journal of the Medical Sciences, vol. 332, no. 2, pp. 103-105, 2006.

[2] W. R. Bennett and D. P. Huston, "Rhabdomyolysis in thyroid storm," American Journal of Medicine, vol. 77, no. 4, pp. 733-735, 1984.

[3] H. Hosojima, R. Iwasaki, E. Miyauchi, H. Okada, and S. Morimoto, "Rhabdomyolysis accompanying thyroid crisis: an autopsy case report," Internal Medicine, vol. 31, no. 10, pp. 12331235, 1992.

[4] M. Alshanti, M. S. Eledrisi, and E. Jones, "Rhabdomyolysis associated with hyperthyroidism," American Journal of Emergency Medicine, vol. 19, no. 4, p. 317, 2001.

[5] M. Cakir, E. Mahsereci, H. Altunbas, and U. Karayalcin, "A case of rhabdomyolysis associated with thyrotoxicosis," Journal of the National Medical Association, vol. 97, no. 5, pp. 732-734, 2005.

[6] H.-R. Kim, S.-H. Kim, and D.-J. Oh, "Rhabdomyolysis after a regular exercise session in a patient with graves' disease," Nephrology, vol. 17, no. 3, pp. 307-308, 2012.

[7] C. Sinclair, J. M. Gilchrist, J. V. Hennessey, and M. Kandula, "Muscle carnitine in hypo- and hyperthyroidism," Muscle and Nerve, vol. 32, no. 3, pp. 357-359, 2005. 


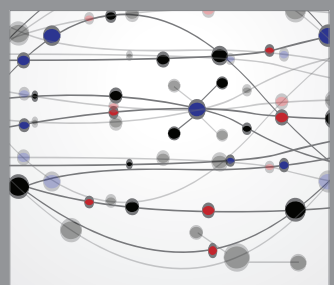

The Scientific World Journal
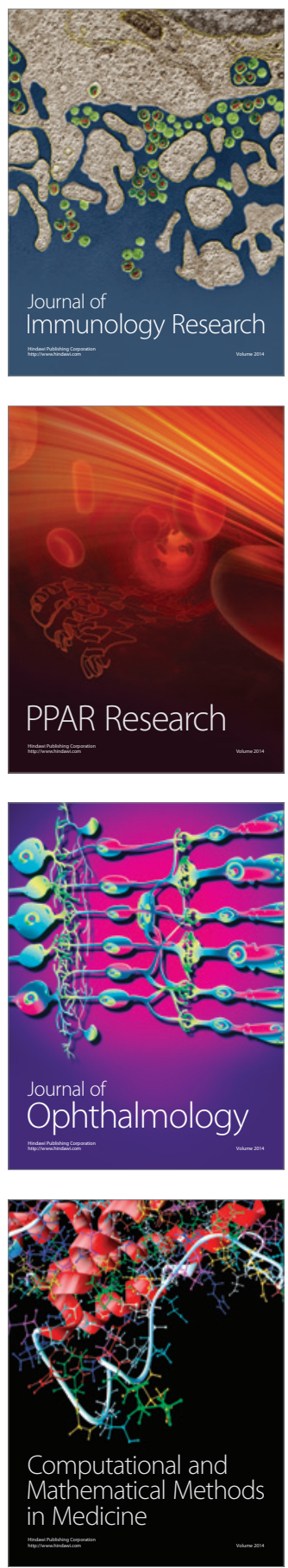



Gastroenterology

Research and Practice
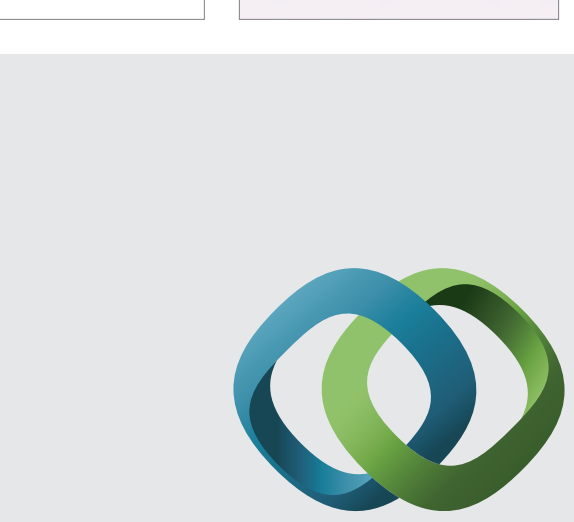

\section{Hindawi}

Submit your manuscripts at

http://www.hindawi.com

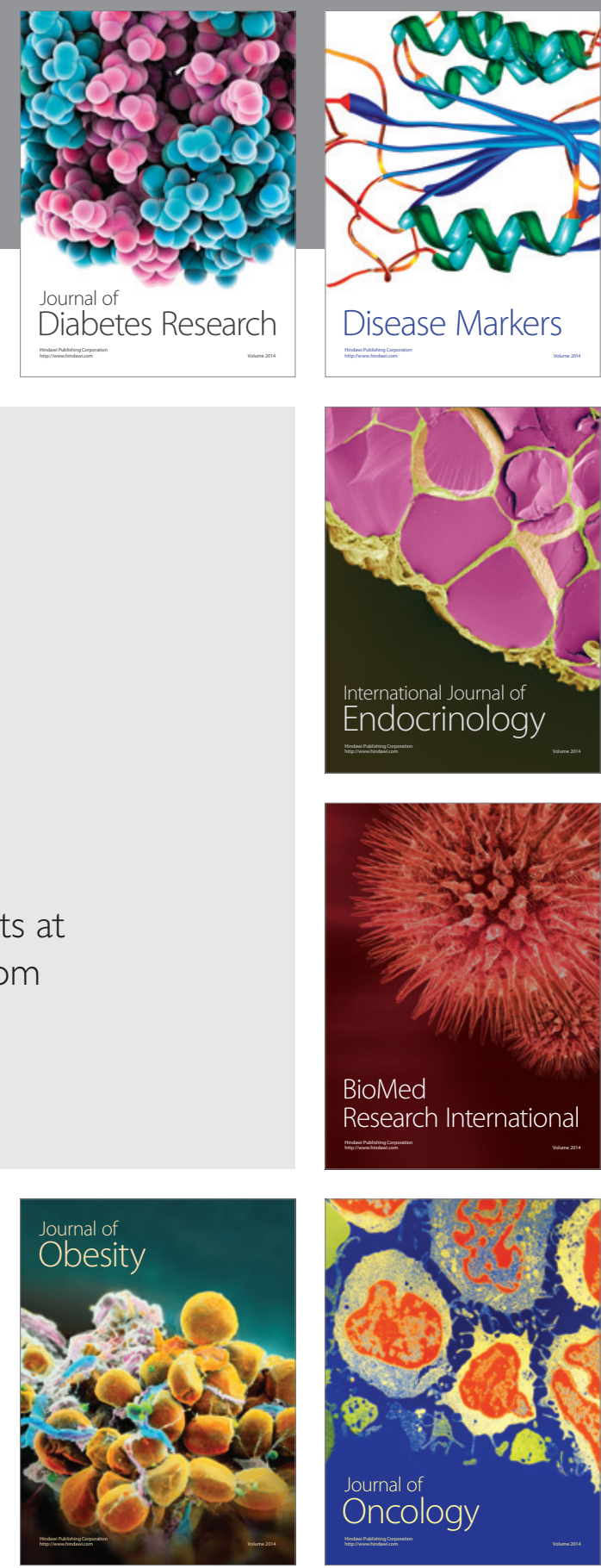

Disease Markers
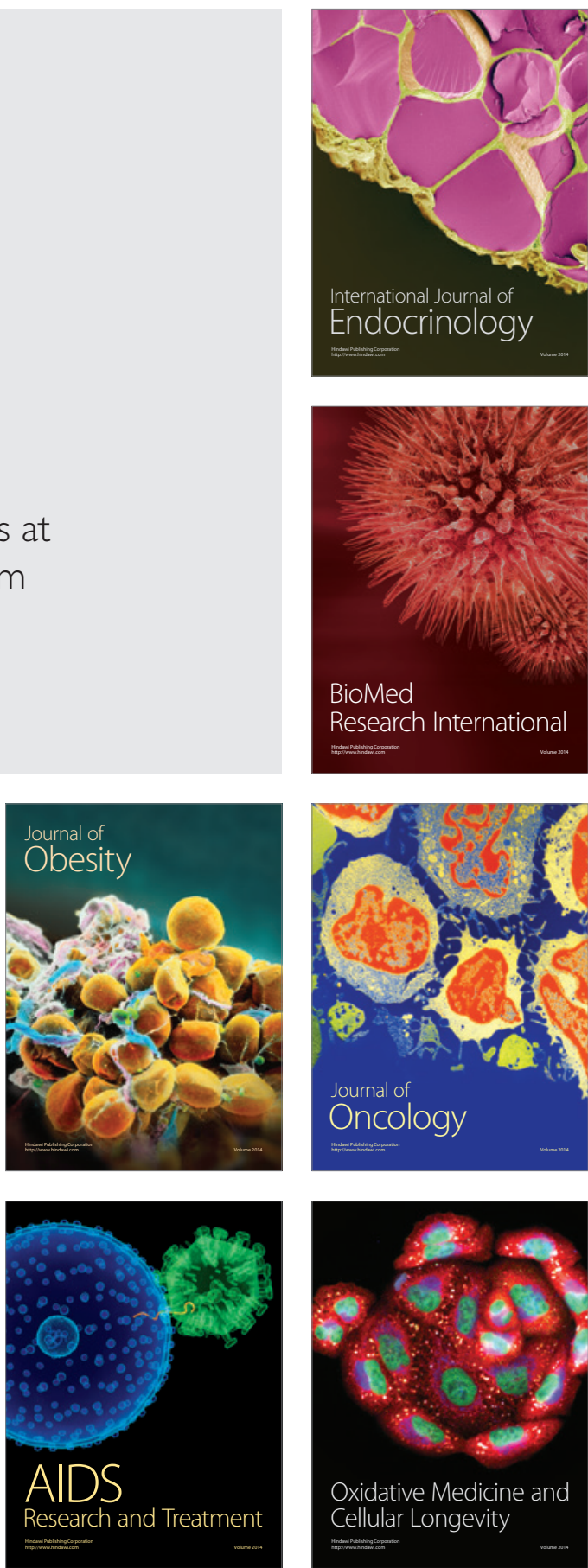